\title{
Knowledge and Attitude toward the Therapeutic Potential of Human Amnion Stem Cells among Students of Taif University, Saudi Arabia
}

\author{
Majid Alhomrani ${ }^{1,2, *}$, Abdulhakeem S Alamri ${ }^{1,2}$, Walaa F Alsanie ${ }^{1,2}$, Bassem M Raafat ${ }^{3}$, \\ Tariq Altalhi ${ }^{4}$, Nujood S Alotaibi', Fay T Algthami ${ }^{1}$, Reyouf H Alsalmi ${ }^{1}$, Najwa H Alhalifi', \\ Syed Mohammed Basheeruddin Asdaq ${ }^{5}$, Nagaraja Sreeharsha ${ }^{6,7}$ \\ 'Department of Clinical Laboratory Sciences, College of Applied Medical Sciences, Taif University, Taif, SAUDI ARABIA. \\ ${ }^{2}$ Centre of Biomedical Sciences Research (CBSR), Deanship of Scientific Research, \\ Taif University, SAUDI ARABIA. \\ ${ }^{3}$ Department of Radiological Sciences, College of Applied Medical Sciences, Taif University, Taif, SAUDI ARABIA. \\ ${ }^{4}$ Department of Chemistry, College of Sciences, Taif University, Taif, SAUDI ARABIA. \\ ${ }^{5}$ Department of Pharmacy Practice, College of Pharmacy, AIMaarefa University, Dariyah, Riyadh, SAUDI ARABIA. \\ ${ }^{6}$ Department of Pharmaceutical Sciences, College of Clinical Pharmacy, King Faisal University, Al-Hofuf, Al-Ahsa, SAUDI ARABIA. \\ ${ }^{7}$ Department of Pharmaceutics, Vidya Siri College of Pharmacy, Off Sarjapura Road, Bangalore, Karnataka, INDIA.
}

\begin{abstract}
Background: Among the various types of stem cells which have been suggested for therapeutic purposes, human amnion epithelial cells (hAEC) are highly promising. Purpose: This study aims to assess the knowledge and attitudes of the Taif University population toward the therapeutic potential of hAEC. Methods: This was a cross-sectional study carried out among the students of Taif University. A self-administrated questionnaire was used in this descriptive study. The questionnaire consisted of demographic information, knowledge, and attitudes regarding stem cells and hAEC. The data was analyzed using descriptive statistics in SPSS-IBM 25. Results: Out of 1026 subjects, 908 (88.6\%) were female, $686(66.9 \%)$ from the age group of less than 25 years, $984(96 \%)$ Saudi nationals, and $834(81.45 \%)$ were undergraduate students. Unfortunately, $35 \%$ of the subjects in this study have no idea about stem cells and $55 \%$ have never heard about hAEC. Only a moderate level of knowledge score was noticed among the participants about stem cells. Significantly $(P=0.001)$ high percentage of females would like to conserve their human amniotic epithelial cells for family or for research purposes. More than $88 \%$ of the subjects would like to have awareness programs in the community about human amniotic epithelial cells. The knowledge and attitude scores were shown to have a substantial positive association. Conclusion: As a result of this research, it is suggested that various stem cell educational programs and awareness campaigns need to be implemented in universities in order to improve stem cell knowledge and encourage a more positive attitude toward the use of stem cells for therapeutic purposes.
\end{abstract}

Key words: Human amniotic epithelial cells, Knowledge, Attitude, Taif University, Awareness campaigns.

\section{INTRODUCTION}

Stem cells are unique in that they have the ability to self-renew indefinitely and can specialize into numerous cell types. Embryonic stem cells (ESC) are pluripotent, which means they can differentiate into any form of cell in the body. As a result, ESCs are critical in the development of a wide supply of tissues for the treatment of disorders like Parkinson's disease, Alzheimer's disease, spinal cord injury, and cardiovascular disease. Nevertheless, because ESC research necessitates the destruction of embryos in order to access the cells, it has sparked ethical, legal, and social debate., ${ }^{1,2}$ This has resulted
Submission Date: 17-07-2021; Revision Date: 24-08-2021; Accepted Date: 10-09-2021

DOI: 10.5530/ijper.55.3s.169 Correspondence: Dr. Majid Alhomrani, Department of Clinical Laboratory Sciences, College of Applied Medical Sciences, Taif University, Taif, SAUDI ARABIA. Email - m.alhomrani@tu.edu. sa

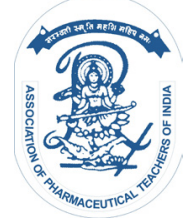

www.ijper.org 
in a demand for alternate stem cell sources that do not require the destruction of an embryo, such as umbilical cord blood stem cells (UCBSCs) and adult stem cells (ASCs). Because of their strong regenerative capacity, enhanced ability to self-renewal, reduced ability to immune response, and, most notably, their safety and ethical free features, UCBSCs are highly recommended. ${ }^{3}$ However, there are many issue associated with its use including the need for in vitro expansion prior to use it in vivo.

Human amniotic/amnion epithelial cells (hAECs) are derived from the innermost layer of the placenta nearest to the fetus and have been found to be seed cells for allogeneic cell treatments. Due to the fact that a high number of cells can be obtained from single placenta with an average of 100-120 million cells, easy accessible and low cost as well as it comes from the placenta which usually discard after the cesarean delivery of healthy baby which results in no ethical concern associated with hAEC. Interest in the use of hAECs in regenerative medicine has grown over the last two decades. Impressive medical outcomes are reported from animal studies on the use of hAECs in the treatment of neurological problems, ${ }^{47}$ respiratory illnesses, ${ }^{8,9}$ hepatic damage, ${ }^{10,11}$ diabetes, ${ }^{12}$ renal diseases, ${ }^{13}$ cardiac ailments, ${ }^{14}$ healing of wounds and ulcers, ${ }^{15,16}$ and several other diseases. ${ }^{17,18}$ Despite their therapeutic efficacy, hAECs differ in physiological properties, secretory function, and immunomodulatory activity under various settings, resulting in variable consequences depending on the function.

Due to the bright prospect of stem cell-based treatment, it is critical for health care professionals and students of medical and allied health sciences universities to have a basic understanding of stem cells and a favorable attitude toward their use in medicine. The results of research undertaken around the world have been inconsistent. A study performed in 2015 demonstrated a modest understanding of stem cell therapy with a good attitude among nursing students. ${ }^{19}$ One study in Tabuk, Saudi Arabia, found that final-year medical students and doctors had insufficient understanding, attitude, and practice when it came to the use of stem cells in diabetes control. ${ }^{20}$ A Saudi Arabian educational interventional study on stem treatment found insufficient knowledge but a good attitude among nursing students. However, after educational intervention, there was a significant gain in knowledge. ${ }^{21}$ In 1984, Saudi Arabia became the first Arab country to carry out hematopoietic stem cell transplantation (HSCT). Approximately 500 allogeneic transplants are currently performed each year. ${ }^{22}$ Considering stem cell therapy is continuously expanding, it is critical to assess the current state of knowledge and attitudes among future graduates who will work in the health-care profession so that effective efforts can be made to close any gaps that may exist. Also, because human amniotic epithelial are easy to isolate, not required an in vitro expansion prior to use and no ethical concern associated with it since the placenta is usually discard following the delivery. Therefore, by using a cross-sectional study design, we aimed to examine the knowledge and attitudes of Taif University students about human amniotic epithelial cells.

\section{METHODS}

\section{Study design and settings}

This was a cross-sectional study carried out among the students of Taif University. This university is situated in Taif, a Saudi city on the eastern slopes of the Sarawat Mountains in the Makkah area of western Saudi Arabia. More than 1000 students from medical and allied health sciences programs at the university participated in this study, which is almost $50 \%$ of the registered students at the university.

\section{Sample size estimation}

The calculation of the sample size was done using Cochrane's sample size equation $\left(n=\mathrm{z}^{2} \mathrm{pq} / \mathrm{e}^{2}\right)$, in which ' $n$ ' indicates the least sample size, while ' $z$ ' stands for the intended confidence interval (95 percent), $\mathrm{p}$ is the proportion, $q=1-p$, and $\mathrm{e}$ is the desired level of precision (5 percent). To calculate the sample size for this investigation, we used $50 \%$ as the population proportion (p). The estimated sample size was computed as 325 using the above formula and values with a finite population of 2100 .

\section{Sampling method}

The study participants were chosen using a multilevel probability proportional to size (PPS) selection approach. To begin, the necessary percentage of participants from each college was determined based on that college's total number of registered students. The required fractions of participants from each year, as well as gender, were chosen based on PPS in the following steps. The systematic random sample method was utilized to choose each gender and year, utilizing each student's university identity number.

\section{Ethical considerations}

This study was approved by Taif University Ethics committee application number (42-0109). Prior to taking part in this study, all respondents were asked to agree or disagree to participate in this research. 


\section{Data collection procedure}

The data collection process began after the appropriate approval processes were completed. The availability of the selected students for data collection was informed to them by their class leader. The study includes all Taif University colleges' registered students for the academic year 2020-21. The research team reached the selected students between December 2020 and February 2021, shared an electronic link to the questionnaire and obtained on-the-spot input. Without compulsion or interference from the researcher, the respondents were free to answer the individual items.

\section{Data collection instrument}

The survey items for this study were created by the researchers based on the most relevant information that needed to be gathered in order to assess knowledge and attitude patterns. With the support of experienced researchers and specialists in the field, both logical and content validity were examined in relation to the study objectives. Following that, the questionnaire was translated into Arabic to make the survey content easier to understand for the surveyors. With the help of bilingual (Arabic-English) speakers, the Arabic translated form was compared to the English version for logical and construction correctness. A pilot study was also conducted on a small sample of the population to see whether there were any missing points or if the responders had any problems understanding the questionnaire items. The questionnaire form had three sections. Section 1 is comprised of demographic variables, including age, gender, educational level, marital status, nationality, and having children. Section 2 was made up of seven items to explore the knowledge of the participants, whereas section 3 included five items to check the pattern of attitude of the surveyors. The classic scoring technique was utilized for this survey ( 1 point for the right and 0 points for the wrong answers in the knowledge section; similarly, 1 point for the positive and 0 points for the negative choices in the attitude section). The score ranges were 0-7 for knowledge, and $0-5$ for attitude, and $0-12$ for the total score of this survey.

\section{Data analysis}

SPSS 25.0 software was used to analyze the data. To compare mean estimations of variables, the $t$-test was used. To compare ratios and demographic variables, the Chi-square test was performed. The correlations between two variables were compared using Pearson and Spearman's correlation. A statistically significant value was defined as $p<0.05$.

\section{RESULTS}

\section{Demographic features of the participants}

The participants (1026) were recruited from different colleges of Taif University. The 908 (88.6\%) participants were female, and only 117 (11.4\%) were male (Table 1$)$. There were $686(66.9 \%)$ students from the age group of less than 25 years, while only $85(8.3 \%)$ participants were from the high age group of more than 45 years. The 984 subjects (96\%) belonged to Saudi Arabian nationality, and $41(4 \%)$ were from non-Saudi origins. The 697 participants (68\%) were single, while 30\% (308) were married and the rest belonged to other categories. A vast majority $(834,81.45 \%)$ of the surveyors were undergraduate students, and $4.6 \%$ of them were postgraduates. Only $274(26.7 \%)$ and $751(73.3 \%)$ have no children.

\section{Knowledge analysis}

Only a moderate level of knowledge was noticed among the participants about stem cells (Table 2). Significantly

\begin{tabular}{|c|c|c|}
\hline Demographics & Frequency & Percentage \\
\hline \multicolumn{3}{|c|}{ Gender } \\
\hline Male & 117 & $11.4 \%$ \\
\hline Female & 908 & $88.6 \%$ \\
\hline \multicolumn{3}{|c|}{ Age } \\
\hline$<25$ years & 686 & $66.9 \%$ \\
\hline $25-35$ years & 154 & $15 \%$ \\
\hline $35-45$ years & 100 & $9.8 \%$ \\
\hline$>45$ years & 85 & $8.3 \%$ \\
\hline \multicolumn{3}{|c|}{ Nationality } \\
\hline Saudi & 984 & $96 \%$ \\
\hline Non-Saudi & 41 & $4 \%$ \\
\hline \multicolumn{3}{|c|}{ Marital status } \\
\hline Single & 697 & $68 \%$ \\
\hline Married & 308 & $30 \%$ \\
\hline Divorced & 14 & $1.4 \%$ \\
\hline Widow & 6 & $0.6 \%$ \\
\hline \multicolumn{3}{|c|}{ Educational status } \\
\hline High school & 144 & $14 \%$ \\
\hline Undergraduates & 834 & $81.4 \%$ \\
\hline Postgraduate & 47 & $4.6 \%$ \\
\hline \multicolumn{3}{|c|}{ Having children } \\
\hline No & 751 & $73.3 \%$ \\
\hline Yes & 274 & $26.7 \%$ \\
\hline
\end{tabular}


Table 2: Percentage description of correct responses on knowledge domain items.

\begin{tabular}{|c|c|c|c|c|c|c|c|c|}
\hline Demographics & K1 & K2 & K3 & K4 & K5 & K6 & K7 \\
\hline \multicolumn{7}{|c|}{ Gender } \\
\hline Male & 64 & 52 & 54 & 52 & 52 & 54 & 49 \\
\hline Female & 68 & 36 & 47 & 47 & 41 & 49 & 44 \\
\hline$P$ value & 0.389 & 0.001 & 0.118 & 0.319 & 0.024 & 0.285 & 0.306 \\
\hline \multicolumn{7}{|c|}{ Age } \\
\hline$<25$ years & 68 & 42 & 50 & 49 & 46 & 48 & 46 \\
\hline $25-35$ years & 63 & 27 & 45 & 45 & 34 & 50 & 45 \\
\hline $35-45$ years & 73 & 33 & 47 & 51 & 42 & 59 & 45 \\
\hline$>45$ years & 64 & 27 & 35 & 44 & 28 & 59 & 31 \\
\hline$P$ value & 0.351 & 0.001 & 0.055 & 0.629 & 0.001 & 0.061 & 0.068 \\
\hline \multicolumn{7}{|c|}{ Nationality } \\
\hline Saudi & 68 & 38 & 48 & 48 & 42 & 50 & 44 \\
\hline Non-Saudi & 56 & 42 & 49 & 51 & 46 & 56 & 39 \\
\hline$P$ value & 0.108 & 0.627 & 0.909 & 0.655 & 0.606 & 0.429 & 0.488 \\
\hline \multicolumn{7}{|c|}{ Marital status } \\
\hline Single & 69 & 43 & 51 & 50 & 46 & 48 & 48 \\
\hline Married & 65 & 27 & 41 & 42 & 33 & 56 & 38 \\
\hline Divorced & 50 & 21 & 43 & 64 & 64 & 38 & 36 \\
\hline Widow & 83 & 17 & 25 & 83 & 18 & 33 & 33 \\
\hline$P$ value & 0.012 & 0.001 & 0.002 & 0.025 & 0.001 & 0.065 & 0.028 \\
\hline \multicolumn{8}{|c|}{ Educational level } \\
\hline High school & 52 & 28 & 42 & 46 & 40 & 52 & 46 \\
\hline Undergraduates & 70 & 39 & 48 & 48 & 42 & 48 & 43 \\
\hline Postgraduate & 75 & 49 & 60 & 60 & 49 & 68 & 66 \\
\hline$P$ value & 0.001 & 0.011 & 0.113 & 0.238 & 0.581 & 0.031 & 0.007 \\
\hline \multicolumn{8}{|c|}{ Having Children } \\
\hline No & 68 & 42 & 50 & 49 & 45 & 48 & 46 \\
\hline Yes & 65 & 28 & 41 & 44 & 35 & 57 & 40 \\
\hline$P$ value & 0.346 & 0.001 & 0.010 & 0.121 & 0.006 & 0.008 & 0.058 \\
\hline
\end{tabular}

$(P=0.001)$ a high proportion of subjects from undergraduate and postgraduate cohorts acknowledged that they have some information about stem cells. Male participants showed significantly $(P=0.001)$ more knowledge about the types of stem cells when compared to the female cohorts. Similarly, those who are unmarried, more educated and without children had more awareness about the types of stem cells. Unfortunately, very few participants were aware of the therapeutic applications and source of stem cells. Males, below 25 years of age, and unmarried subjects had significantly better awareness of human amniotic stem cells compared to other members of their respective groups. The role of the placenta and increased research activities were also not widely disseminated across the participants.
Pearson Chi-Square significance: $P$ value; K1: Do you have any information about stem cells; K2: -Do you know the types of stem cells; K3: Are you aware of the potential therapeutic applications that stem cells provide; K4: Do you know the sources of stem cells; K5: Do you have any information regarding the exits of human amnion epithelial cells (hAEC); K6: Are you aware that placenta considered as the major source of human amnion epithelial cells; K7: Do you have any knowledge about the characteristics that made hAEC the focus of attention for many researchers?

\section{Attitude analysis}

Generally, the attitudes of the participants in this study were positive and inspiring (Table 3). Significantly $(P=0.001)$ high percentage of females would like to

\begin{tabular}{|c|c|c|c|c|c|}
\hline Demographics & A1 & A2 & A3 & A4 & A5 \\
\hline \multicolumn{6}{|c|}{ Gender } \\
\hline Male & $44 \%$ & $81 \%$ & $56 \%$ & $82 \%$ & $94 \%$ \\
\hline Female & $74 \%$ & $95 \%$ & $56 \%$ & $92 \%$ & $97 \%$ \\
\hline$P$ value & 0.001 & 0.001 & 0.990 & 0.001 & 0.144 \\
\hline \multicolumn{6}{|c|}{ Age } \\
\hline$<25$ years & 64 & 94 & 57 & 92 & 96 \\
\hline $25-35$ years & 78 & 90 & 59 & 88 & 96 \\
\hline $35-45$ years & 80 & 96 & 51 & 93 & 96 \\
\hline$>45$ years & 69 & 97 & 45 & 89 & 100 \\
\hline$P$ value & 0.007 & 0.168 & 0.105 & 0.271 & 0.324 \\
\hline \multicolumn{6}{|c|}{ Nationality } \\
\hline Saudi & 71 & 94 & 56 & 92 & 96 \\
\hline Non-Saudi & 56 & 88 & 51 & 76 & 100 \\
\hline$P$ value & 0.045 & 0.116 & 0.564 & 0.001 & 0.206 \\
\hline \multicolumn{6}{|c|}{ Marital status } \\
\hline Single & 69 & 94 & 56 & 91 & 96 \\
\hline Married & 73 & 93 & 53 & 92 & 97 \\
\hline Divorced & 21 & 14 & 77 & 100 & 86 \\
\hline Widow & 17 & 17 & 33 & 50 & 100 \\
\hline$P$ value & 0.387 & 0.480 & 0.167 & 0.002 & 0.154 \\
\hline \multicolumn{6}{|c|}{ Educational level } \\
\hline High School & 63 & 92 & 60 & 83 & 95 \\
\hline Undergraduates & 72 & 94 & 54 & 93 & 97 \\
\hline Postgraduate & 60 & 17 & 62 & 96 & 96 \\
\hline$P$ value & 0.028 & 0.568 & 0.284 & 0.001 & 0.651 \\
\hline \multicolumn{6}{|c|}{ Having Children } \\
\hline No & 69 & 94 & 56 & 92 & 96 \\
\hline Yes & 73 & 93 & 55 & 91 & 97 \\
\hline$P$ value & 0.229 & 0.638 & 0.846 & 0.580 & 0.736 \\
\hline
\end{tabular}


conserve their human amniotic epithelial cells for family or for research purposes. A great majority of the subjects from different age groups, Saudi nationals and undergraduate students, would like to conserve stem cells. More than $88 \%$ of the subjects would like to have awareness programs in the community about human amniotic epithelial cells. Most of the participants from a variety of age groups, marital status, and educational backgrounds emphasized the importance of having stem cell banks in the Kingdom of Saudi Arabia. Overall, $96 \%$ of the surveyors believe that there is a dire need to have a general awareness campaign for stem cells in the Kingdom of Saudi Arabia.

Pearson Chi-Square significance: $P$ value; A1: If you or your spouse become pregnant in the future, would you conserve your hAEC for protecting your family or donate it for research purposes; A2: Do you support increasing the awareness of our community about hAEC by conducting courses, programs or associate it with educational curriculum; A3: Would you be willing to donate, conserve stem cells for personal therapeutic purposes or research; A4: From your opinion, do you think that there is an importance to establish banks for conserving stem cells in Saudi Arabia; A5: Do you think it is important to increase the awareness toward stem cells in Saudi Arabia.

\section{Analysis of participants' response}

According to demographic characteristics (Table 4), the mean ranking for the 'knowledge' score was found to be highest for post graduate subjects (4.51), followed by male participants (4.14), non-Saudis (3.82), those less than 25 years old (3.80) and those who had no children (3.79). In the 'attitude' domain, divorced subjects scored the highest (4.28), followed by female participants (4.13). Overall, the mean score of attitude from most of the cohorts was better than the mean score of knowledge. A significantly $(P=0.049)$ lowered level of knowledge score was noticed among 'widow' subjects. The total score was highest among postgraduate subjects (8.57) and, significantly $(P=0.002)$, they differed from other participants from their cohort.

\section{DISCUSSION}

University students' knowledge and attitudes about stem cells are critical because they will serve as a dependable source of information for patients, improving their decision-making capacity when it comes to using stem cells as a unique and innovative therapeutic strategy. ${ }^{23}$ The outcome of the study demonstrates a moderate level of knowledge about human amniotic epithelial cells with a positive attitude among the Taif University students.

\begin{tabular}{|c|c|c|c|c|c|c|c|}
\hline \multicolumn{2}{|c|}{ Demographic Variable } & K-Score & $P$ value & A-Score & $P$ value & Total Score & $P$ value \\
\hline \multirow{2}{*}{ Gender } & Male & $4.14 \pm 1.23$ & \multirow{2}{*}{0.088} & $3.56 \pm 1.22$ & \multirow{2}{*}{0.289} & $7.7 \pm 1.22$ & \multirow[t]{2}{*}{0.676} \\
\hline & Female & $3.64 \pm 1.10$ & & $4.13 \pm 1.03$ & & $7.77 \pm 1.06$ & \\
\hline \multirow{4}{*}{ Age } & $<25$ years & $3.80 \pm 1.09$ & \multirow{4}{*}{0.102} & $4.05 \pm 1.09$ & \multirow{4}{*}{0.281} & $7.85 \pm 1.09$ & \multirow[t]{4}{*}{0.543} \\
\hline & 25-35years & $3.45 \pm 1.24$ & & $4.11 \pm 0.11$ & & $7.56 \pm 0.67$ & \\
\hline & 35-45years & $3.77 \pm 1.11$ & & $4.16 \pm 0.04$ & & $7.93 \pm 0.57$ & \\
\hline & $>45$ years & $3.23 \pm 1.09$ & & $4.00 \pm 0.93$ & & $7.23 \pm 1.01$ & \\
\hline \multirow{2}{*}{ Nationality } & Saudi & $3.69 \pm 1.11$ & \multirow{2}{*}{0.112} & $4.08 \pm 1.07$ & \multirow{2}{*}{0.318} & $7.77 \pm 1.09$ & \multirow[t]{2}{*}{0.218} \\
\hline & Non-Saudi & $3.82 \pm 1.30$ & & 3. $70 \pm 1.06$ & & $7.52 \pm 1.18$ & \\
\hline \multirow{4}{*}{ Marital status } & Single & $3.86 \pm 1.13$ & \multirow{4}{*}{0.049} & $4.06 \pm 1.09$ & \multirow{4}{*}{0.563} & $7.92 \pm 1.11$ & \multirow[t]{4}{*}{0.024} \\
\hline & Married & $3.37 \pm 1.03$ & & $4.08 \pm 1.03$ & & $7.45 \pm 1.03$ & \\
\hline & Divorced & $3.64 \pm 1.09$ & & $4.28 \pm 1.09$ & & $7.92 \pm 1.09$ & \\
\hline & Widow & $2.00 \pm 0.52$ & & $3.66 \pm 1.10$ & & $5.66 \pm 0.81$ & \\
\hline \multirow{3}{*}{$\begin{array}{l}\text { Educational } \\
\text { qualification }\end{array}$} & High School & $3.54 \pm 1.23$ & \multirow{3}{*}{0.310} & $3.93 \pm 1.15$ & \multirow{3}{*}{0.743} & $7.47 \pm 1.19$ & \multirow[t]{3}{*}{0.002} \\
\hline & Undergraduates & $3.68 \pm 1.09$ & & $4.09 \pm 1.06$ & & $7.77 \pm 1.07$ & \\
\hline & Postgraduate & $4.51 \pm 1.18$ & & $4.06 \pm 0.97$ & & $8.57 \pm 1.07$ & \\
\hline \multirow{2}{*}{ Having Children } & No & $3.79 \pm 1.11$ & \multirow{2}{*}{0.322} & $4.06 \pm 1.08$ & \multirow{2}{*}{0.654} & $7.85 \pm 1.09$ & \multirow[t]{2}{*}{0.432} \\
\hline & Yes & $3.44 \pm 1.12$ & & $4.08 \pm 1.05$ & & $7.52 \pm 1.08$ & \\
\hline
\end{tabular}

$\mathrm{K}$-Score $=$ Average knowledge score; A-Score $=$ Average attitude score Values are given as mean \pm SD. Statistics: One-way Anova and T-test followed by appropriate non-parametric tests depending on variables. $n=1026 ; P>0.05$ compared within groups 
The majority of the participants included in this study were female. However, their mean knowledge score was lower than the males. This finding is in contrast to the general belief that females are more knowledgeable and have more awareness of their surroundings. Lack of communication and media role in disseminating information about human amniotic epithelial cells (hAEC) is possibly the reason for attaining this low knowledge score. Unfortunately, around $35 \%$ of the subjects in this study have no idea about stem cells and 55\% have never heard about hAEC. Altemani et al., $2018^{20}$ conducted a study on doctors and medical students in Tabuk city to see how well they understood stem cell therapy for diabetes mellitus, and found that 76.5 percent had fair knowledge. The participants in the bulk of other Saudi Arabian studies have shown that they are unaware of stem cells. Most of the other Saudi Arabian investigations have found that the participants had little awareness of stem cells. In their study on the significance of stem cells in dentistry, Alhadlaq et al. (2019) ${ }^{24}$ discovered a lack of understanding among both male and female students. Further, nursing students showed poor knowledge in another study (Azzazy and Mohamed, 2019 $)^{21}$ done in Saudi Arabia that improved significantly after educational intervention.

A great majority of the subjects, both male and female, agree that there is a need to have a mass awareness campaign to disseminate knowledge of stem cells and also that there is a necessity to establish banks for conserving stem cells in Saudi Arabia. The findings in this study are congruent with an earlier report ${ }^{19}$ that observed $76.1 \%$ of the nursing students having a good attitude towards stem cell applications in medical sciences. ALtemani et al., $2018^{20}$ found a positive attitude of the study participants towards stem cells and their implications in medicine. The participants' commitment to conserving stem cells for their family and research purposes is very admirable, as these subjects are going to play a major role in decision making processes in the future. Generally, both attitude and knowledge scores were high among postgraduate students. It is obvious that they are more aware and have an inspirational positive attitude. That is a good sign for community improvement.

We discovered a strong positive association between knowledge and attitudes in the current study, which is consistent with previous studies published in Saudi Arabia. ${ }^{25}$ Although the knowledge level was moderate for most of the questions, the attitude to uplifting the knowledge and enhancing awareness were high. Our findings are in disagreement with a study done earlier ${ }^{19}$ on Malaysian nursing students where a poor correlation between knowledge and attitude was noted that they attributed to being influenced by religious and cultural issues. Although Saudi Arabia is a capital for Islamic knowledge, Saudi society has kept themselves updated with the medical needs within the fulcrum of religion. Also, it is possible that the Malaysian study was carried out in 2015. Stem cell research has taken a long leap since then and Malaysian society must have accommodated the importance of stem cells in their culture.

This study has some limitations, such as the use of a convenient sampling technique in subject selection, which limits the generalizability of the findings to all Taif University students. Because of the cross-sectional character of this study, causality between the studied variables could not be determined.

\section{CONCLUSION}

The majority of the participants had a moderate degree of knowledge, as well as a positive attitude regarding stem cells and their importance. The knowledge and attitude scores were shown to have a substantial positive association. As a result of this research, it is suggested that various stem cell educational programs and awareness campaigns need to be implemented in universities in order to improve stem cell knowledge and encourage a more positive attitude toward the use of stem cells for therapeutic purposes.

\section{Funding}

Majid Alhomrani would like to acknowledge Taif University for support No. TURSP (2020/257)

\section{CONFLICT OF INTEREST}

The authors declare that there is no conflict of interest.

\section{SUMMARY}

Stem cell education and awareness campaigns should be undertaken at universities to increase stem cell understanding and foster a more favorable attitude toward the use of stem cells for therapeutic reasons.

\section{REFERENCES}

1. Nisbet MC. Public opinion about stem cell research and human cloning. Public Opin Q. 2004;68(1):131-54. doi: 10.1093/Poq/Nfh009, Google Scholar.

2. Robertson JA. Embryo stem cell research: ten years of controversy. J Law Med Ethics. 2010;38(2):191-203. doi: 10.1111/j.1748-720X.2010.00479.x, PMID 20579242, Google Scholar.

3. Ikuta LM. Human umbilical cord blood transplantation: what nurses need to know. AACN Adv Crit Care. 2008;19(3):264-7. doi: 10.1097/01. AACN.0000330376.11272.8b, PMID 18670200, Google Scholar. 
4. Xu H, Zhang J, Tsang KS, Yang H, Gao WQ. Therapeutic potential of human amniotic epithelial cells on injuries and disorders in the central nervous system. Stem Cells Int. 2019;2019:5432301. doi: 10.1155/2019/5432301.

5. Kim KY, Suh YH, Chang KA. Therapeutic effects of human amniotic epithelial stem cells in a transgenic mouse model of Alzheimer's disease. Int $\mathrm{J}$ Mol Sci. 2020;21(7):2658. doi: 10.3390/ijms21072658, PMID 32290355.

6. Wu ZY, Hui GZ, Lu Y, Wu X, Guo LH. Transplantation of human amniotic epithelial cells improves hindlimb function in rats with spinal cord injury. Chin Med J (Engl). 2006;119(24):2101-7. doi: 10.1097/00029330-200612020-00013, PMID 17199962.

7. Van den Heuij LG, Fraser M, Miller SL, Jenkin G, Wallace EM, Davidson JO, Lear CA, Lim R, Wassink G, Gunn AJ, Bennet L. Delayed intranasal infusion of human amnion epithelial cells improves white matter maturation after asphyxia in preterm fetal sheep. J Cereb Blood Flow Metab. 2019;39(2):223-39. doi: 10.1177/0271678X17729954, PMID 28895475.

8. He F, Zhou A, Feng S. Use of human amniotic epithelial cells in mouse models of bleomycin-induced lung fibrosis: A systematic review and meta-analysis. PLOS ONE. 2018;13(5):e0197658. doi: 10.1371/journal.pone.0197658, PMID 29772024.

9. Hodges RJ, Lim R, Jenkin G, Wallace EM. Amnion epithelial cells as a candidate therapy for acute and chronic lung injury. Stem Cells Int. 2012;2012:709763. doi: 10.1155/2012/709763.

10. Andrewartha N, Yeoh G. Human amnion epithelial cell therapy for chronic liver disease. Stem Cells Int. 2019;2019:8106482. doi: 10.1155/2019/8106482.

11. Alhomrani M, Correia J, Zavou M, Leaw B, Kuk N, Xu R, Saad MI, Hodge A, Greening DW, Lim R, Sievert W. The human amnion epithelial cell secretome decreases hepatic fibrosis in mice with chronic liver fibrosis. Front Pharmacol. 2017 Oct 24;8:748. doi: 10.3389/fphar.2017.00748, PMID 29114223, PMCID PMC5660722.

12. Lebreton F, Lavallard V, Bellofatto K, Bonnet R, Wassmer $\mathrm{CH}$, Perez L, Kalandadze V, Follenzi A, Boulvain M, Kerr-Conte J, Goodman DJ, Bosco D, Berney T, Berishvili E. Insulin-producing organoids engineered from islet and amniotic epithelial cells to treat diabetes. Nat Commun. 2019;10(1):4491. doi: 10.1038/s41467-019-12472-3, PMID 31582751.

13. Liu J, Hua R, Gong Z, Shang B, Huang Y, Guo L, Liu T, Xue J. Human amniotic epithelial cells inhibit CD4+ T cell activation in acute kidney injury patients by influencing the miR-101-c-Rel-IL-2 pathway. Mol Immunol. 2017;81:76-84. doi: 10.1016/j.molimm.2016.11.019, PMID 27898347.

14. Song YS, Joo HW, Park IH, Shen GY, Lee Y, Shin JH, et al. Transplanted human amniotic epithelial cells secrete paracrine proangiogenic cytokines in rat model of myocardial infarction. Cell Transplant. 2015;24(10):2055-64. 11. doi: 10.3727/096368914X685609, PMID 25420194.

15. Zhao B, Liu JQ, Zheng Z, Zhang J, Wang SY, Han SC, et al. Human amniotic epithelial stem cells promote wound healing by facilitating migration and proliferation of keratinocytes via ERK, JNK and AKT signaling pathways. Cell Tissue Res. 2016;365(1):85-99. 12. doi: 10.1007/s00441-016-2366-1, PMID 26888423.
16. Zheng X, Jiang Z, Zhou A, Yu L, Quan M, Cheng H. Pathologic changes of wound tissue in rats with stage III pressure ulcers treated by transplantation of human amniotic epithelial cells. Int J Clin Exp Pathol. 2015;8(10):12284-91. 13. PMID 26722414.

17. Li B, Zhang Q, Sun J, Lai D. Human amniotic epithelial cells improve fertility in an intrauterine adhesion mouse model. Stem Cell Res Ther. 2019;10(1):257. doi: 10.1186/s13287-019-1368-9, PMID 31412924.

18. Zhang Q, Xu M, Yao X, Li T, Wang Q, Lai D. Human amniotic epithelial cells inhibit granulosa cell apoptosis induced by chemotherapy and restore the fertility. Stem Cell Res Ther. 2015;6:152. doi: 10.1186/s13287-015-0148-4, PMID 26303743.

19. Lye et al. 2015. Lye JL, Soon LK, Wan Ahmad WAN, Tan SC. Knowledge and attitude about stem cells and their application in medicine among nursing students in Universiti Sains Malaysia, Malaysia. Malays J Med Sci. 2015;22(4):23-31. (PMC Free article). PMID 26715905, Google Scholar.

20. ALtemani et al. ALtemani MF, ELBeltagy M, ALmashori MM, ALaradi BI, majed ALtoairqi L; 2018. Swead FA, Mirghani HO, Ibrahim Y. Knowledge, attitude and practice of doctors and medical students towards stem cell use in the management of diabetes mellitus. Egypt J Hosp Med. 2018;71:3308-13. Google Scholar.

21. Azzazy, Mohamed. Azzazy MH, Mohamed FH. Effect of educational intervention on knowledge and attitude of nursing students regarding stem cells therapy. IOSR JNHS. 2016;5:75-80. Google Scholar.

22. Shaheen M, Almohareb F, Aljohani N, Ayas M, Chaudhri N, Abosoudah I, Alotaibi S, Alshahrani M, Alsharif F, Akhtar S, Alhumaidan H, Rasheed W, Alfraih F, Al-Anazi K, Alhashmi H, Al-Daama S, Hanbali A, Alsaleh K, Alzahrani H, Ibrahim K, Alawwami M, Albeirouti B, Albeihany A, Alabdulwahab A, Motabi I, Zaidi SZA, Ahmed SO, Aljefri A, Hussain F, Alahmari A, Hashmi S, Elsolh H, Alseraihy A, Aljurf M. Hematopoietic stem cell transplantation in Saudi Arabia between 1984 and 2016: experience from four leading tertiary care hematopoietic stem cell transplantation centers. Hematol Oncol Stem Cell Ther. 2021;14(3):169-78. doi: 10.1016/j.hemonc.2020.07.008, PMID 32888899.

23. Tork et al. 2017. Tork H, Alraffaa S, Almutairi K, Alshammari N, Alharbi A, Alonzi A. Stem cells: knowledge and attitude among health care providers in Qassim region, KSA. Int J Adv Nurs Stud. 2017;7(1):1-7. doi: 10.14419/ijans. v7i1.8524, Google Scholar.

24. Alhadlaq et al. 2019. Alhadlaq A, Al-Maflehi N, Alzahrani S, AlAssiri A. Assessment of knowledge and attitude toward stem cells and their implications in dentistry among recent graduates of dental schools in Saudi Arabia. Saudi Dent J. 2019;31(1):66-75. doi: 10.1016/j.sdentj.2018.10.006. (PMC Free article). PMID [CrossRef], Google Scholar.

25. Almaeen A, Wani FA, Thirunavukkarasu A. Knowledge and attitudes towards stem cells and the significance of their medical application among healthcare sciences students of Jouf University. PeerJ. 2021 Jan 19;9:e10661. doi: 10.7717/peerj.10661, PMID 33552720, PMCID PMC7821763.

Cite this article: Alhomrani M, Alamri AS, Alsanie WF, Raafat BM, Altalhi T, Alotaibi NS, et al. Knowledge and Attitude toward the Therapeutic Potential of Human Amnion Stem Cells among Students of Taif University, Saudi Arabia. Indian J of Pharmaceutical Education and Research. 2021;55(3s):s630-s636. 